\title{
Trends in Hydropower Development in Nepal
}

Despite long history of hydropower development in Nepal, there still persists various hurdles and drawback in hydropower sector. It seems that Nepal's hydro-bureaucracy is slow to understand the right thing to do. Some of the examples are given below;

1. It took about 20 years for the hydro-bureaucracy of the Nepal Government to understand that private sector is not capable to develop sufficient hydropower projects to satisfy the demand; and the public sector must play a substantial and major role for implementation of hydropower projects.

2. Similarly, after more than 20 years Nepal's hydrobureaucracy has yet to understand the reality that Indian Power market is not open to Nepal, especially if it is developed by other than the Indian companies. It is still dreaming of exporting substantial power to earn hydro- rupees/ dollars. Sixteen years of efforts failed to develop West Seti HEP (750 MW). It is a clear signal that Indian power market is not open to Nepal.

3. Electricity Emergency Alleviation Plan has set subsidy of $75 \%$ for below $1 \mathrm{MW}$ and $50 \%$ subsidy in the construction cost for below 3MW of hydro projects if implemented by cooperatives or Village development Committee (VDC)/District Development Committee (DDC). One MW project will cost about Rs.170 million and three MW will cost about Rs.460-480 million. It is very strange why the Govt. want to subsidize the huge construction cost. It is difficult to digest. Critics claim that it is an excuse to distribute funds to party cadres.

4. Former Finance Ministers Dr. Babu Ram Bhattarai and Mr. Surendra Raj Pandey both declared in their respective Budget speech that there will be no license required for the hydro projects of upto 3MW capacity. The Draft Electricity Act- 2065 tabled in the Parliament also has stipulations that no license is required for upto $3 \mathrm{MW}$ capacity. This will create a positive environment for the development of small hydro. However, the proposed Electricity Emergency Alleviation Plan is silent on this issue. The government does not do what is required. It does what is not required.

5. It has been announced a People's Hydropower for constructing upto $25 \mathrm{MW}$ hydro project by District Development Committee (DDC) and local institutions. It is a good initiative to have people's hydropower. The concern is the capability of the local institutions. $25 \mathrm{MW}$ is too big for a DDC in terms of its managerial, technical, and financial capability. State owned agency NEA and reputed private developers are getting tough times to develop even a small project. To begin with 1-2 MW would be realistic for DDC and after completion; larger capacity may be taken afterwards.

6. It is very strange why the recently established Hydropower Investment and Development Company would invest only projects larger than $25 \mathrm{MW}$. Even the Prime Minister JN Khanal during the inauguration expressed his concern with the $25 \mathrm{MW}$ criterion and suggested to lower the ceiling to 5MW. Above examples clearly illustrates the capability of local developers and this criterion will only benefit the foreign license holders of hydro development.

7. Hydropower development in Nepal is a Herculean Task. For example, Khudi HEP 4MW developed by the top Hydro Developer of Nepal is not free of troubles. Presently, it is a loss making project. Further, 5 MW Mailung Khola HEP is promoted by the hydro power Engineers/professionals who have spent their life time in hydro projects. The project has backing of Russian Non Resident Nepalese. There is already penalty of Rs.6o million for delays as Per Power Purchase Agreement (PPA). The PPA rate is of the late Shailaja Minister's time which is totally unviable for the developer at present market price. After 9 years of efforts, only recently the project construction started.

8. Many of the Developers do not understand the Time Value of money. Some have signed PPA with out any annual escalation clause. Presently, the NEA has increased PPA rates by $20 \%$; however, the annual escalation of $3 \%$ has been reduced from nine to three times only. Responsible Govt./ NEA Officers must realize that when the annual general inflation in the country is double digit, how can a mere $3 \%$ that is too only for 3 times is justified. Rs. 6 per unit of PPA rate after 25 years may be equivalent to far less than Rs.1 at today's price.

9. Department of Electricity Development of Nepal is distributing licenses. License issue to foreign companies for a mere $10 \%$ royalty should stop. It needs to be thoroughly studied in detail for the best options to issue licenses.

Now let us see some of the announcement of Energy Minister Honorable Gokarna Bista. Following are some of the suggestions.

- Declaring reduction of electricity loss by $9 \%$ in six months. It is a very ambitious target. It is a positive step to lower the theft of electricity. However, it needs to be noted that the theft by hooking in the main lines or in domestic use will be far less than $3 \%$ of the loss. The major losses/ theft are in the industries and in big Hotels. It is heard that, these industries are taking advantages with collision of the NEA staff. Any substantial reduction in loss should be targeted in the industries and big Hotels. Further, capacity increase in the transmission lines is not progressing well. Improvement in the transmission lines is necessary to reduce the electricity losses.

- Announcing to complete DPR of Budhi Gandaki 6ooMW in this fiscal year is a positive step. It needs to be noted that private sector can not take the responsibility to resettlement rehabilitation of about 15,000 persons to be displaced from the reservoirs. Upper Seti $127 \mathrm{MW}$ is under Detailed Design with support from ADB. Further for the purpose of system balance and addition of power, this project needs to be implemented in a fast track. It is not heard in the media. Pre-qualification of the probable contractors, and rehabilitation/resettlement initiation works need to be undertaken to take this project in a fast track. 